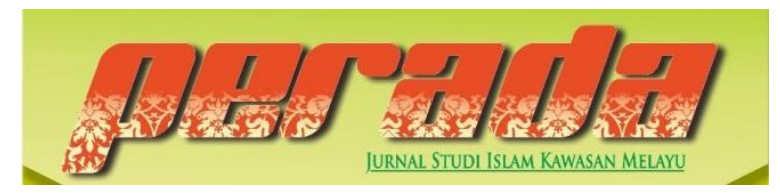

\author{
Perada: Jurnal Studi Islam Kawasan Melayu \\ P-ISSN 2656-7202 E-ISSN 2655-6626 \\ Volume 2 Nomor 1, Januari-Juni 2019 \\ DOI: $10.35961 /$ perada.v2i1.25
}

\title{
BUGIS DI KERAJAAN MELAYU: Eksistensi Orang Bugis dalam Pemerintahan Kerajaan Johor-Riau-Lingga-Pahang
}

\author{
Syahrul Rahmat \\ STAIN Sultan Abdurrahman Kepulauan Riau \\ syahrul28@gmail.com
}

\begin{abstract}
Abstrak
Kondisi geografis Semenanjung Melayu sebagai lalu lintas perdagangan kawasan Asia bagian Tenggara membuat daerah ini menjadi tujuan pelayaran dari berbagai etnis di Nusantara maupun dari belahan dunia lain, termasuk Orang Bugis yang berasal dari daratan Sulawesi bagian selatan. Dalam perkembangannya, selain untuk mencari penghidupan, lambat laun mereka mulai masuk ke dalam struktur pemerintahan Kerajaan Johor-Riau-Lingga-pahang. Kehadiran orang bugis dalam struktur pemerintahan tersebut mengalami dinamika tersendiri terhadap kerajaan yang kelak berubah nama menjadi Kerajaan Riau Lingga. Penelitian ini merupakan penelitian sejarah dengan fokus pada dinamika politik dan eksistensi orang Bugis dalam Kerajaan Melayu pada rentang abad ke-17 hingga 18. Selain merubah struktuur pemerintahan, posisi sebagai Yang Dipertuan Muda yang dijabat keturunan juga membawa perubahan terhadap perkembangan kerajaan tersebut. Sekalipun demikian, Yang Dipertuan Muda juga harus menghadapi konflik internal dalam kerajaan akibat dominasi mereka dalam usrusan pemerintahan.
\end{abstract}

Kata kunci: Bugis, Melayu, Kerajaan Johor-Riau-Lingga-Pahang,

\begin{abstract}
The geographical conditions of the Malay Peninsula as the trade traffic in the Southeast Asian region make this area a destination for shipping from various ethnic groups in the archipelago as well as from other parts of the world, including the Bugis people from the southern Sulawesi mainland. In its development, in addition to make a living, they gradually begin to join the government structure of the Johor-Riau-Lingga-Pahang Kingdom. Bugis existence in the government structure experiences its own dynamics towards the kingdom which later changes its name to the Kingdom of Riau Lingga. This research is a historical study with a focus on the political dynamics and the existence of Bugis in the Malay Kingdom in the 17th to 18th century. Besides changing the structure of government, the position as the Crown Prince, which was held by descendants also gives changes to the development of the kingdom. Even so, the Crown Prince must face internal conflicts in the kingdom due to their dominance in the government administration.
\end{abstract}

Keywords: Bugis, Melayu, Johor-Riau-Lingga-Pahang Kingdom 


\section{PENDAHULUAN}

Secara garis besar, etnis Bugis dikenal sebagai orang-orang yang mendiami wilayah Sulawesi bagian selatan. Tidak hanya wilayah pesisiran pantai, tetapi mereka juga menetap hingga ke daerah pegunungan. Beberapa daerah yang menjadi tempat bermukim atau asal orang Bugis di antaranya adalah Bone, Luwuk, Wajo, Bulukumba, Soppeng, Maros Palopo, Sinjai, Pangkajene, Enrekang, Selayar, Pinrang, Makasar dan Pare-Pare. ${ }^{1} \quad$ Mereka dikenal sebagai pengarung lautan dan tercatat telah singgah dan bahkan menetap di berbagai daerah di Nusantara.

Terkait dengan para perantau Bugis yang ada di kawasan semenanjung Melayu dan beberapa pulau di daerah Kepulauan Riau, mereka dikenal sebagai saudagar yang terkenal. Seorang berkebangsaan Inggris bernama Francis Light yang pernah datang ke Pulau Pinang, Malaysia pada 11 Agustus 1786 menyebutkan orang-orang Bugis adalah saudagar yang paling terkenal di pulaupulau sebelah timur. Disebutkan mereka memiliki dagangan bernilai tinggi, sama dengan emas bungkah bersama-sama dengan beberapa candu serta kain baju. Hal ini kemudian membuat kedatangan mereka begitu ditunggu dan diharapkan oleh para pedagang. ${ }^{2}$

Dari berbagai wilayah yang tercatat pernah disinggahi, kawasan semenanjung Melayu adalah salah satu lokasi yang menjadi tujuan orang-orang Bugis. Sebagai kawasan strategis dalam hal perdagangan, daerah ini menjadi tujuan oleh banyak pedagang dari berbagai daerah. Keberadaan Malaka serta kekuasaan Islam di Aceh menjadi

\footnotetext{
${ }^{1}$ Faisal Sofyan, Sejarah Persemendaan Melayu dan Bugis, (Tanjung Pinang: Milaz Grafika, 2013), h.16

2 Daud Kadir, dkk. Sejarah Kesultanan Lingga-Riau (Pemerintah Kabupaten Lingga Provinsi Kepulauan Riau, 2008), h.86
}

semacam pasar tempat terjadinya transaksi bagi para pedagang. Tidak hanya pada masa Islam, aktivitas pelayaran dan perdagangan di kawasan ini bahkan telah ada sejak zaman Hindu-Budha dan bahkan sebelumnya. ${ }^{3}$

Pada masa kejayaan Kerajaan Melayu Malaka yang terkenal sebagai pusat perdagangan, orang Bugis merantau dalam rangka bedagang atau mencari penghidupan yang lebih baik. Akan tetapi hal tersebut mulai berubah pada masamasa mendatang. Mereka datang ke daerah barat tidak semata untuk mencari penghidupan, melainkan didorong oleh faktor lain. Migrasi besar-besaran orang Bugis juga disebabkan perang VOC di Makassar yang kemudian berakhir dengan perjanjian Bungaya pada November $1667 .^{4}$

Dalam perkembangannya, perpindahan migrasi orang Bugis mulai terjadi diakibatkan berbagai faktor. Alasan keamanan akibat situasi politik serta alasan perekonomian juga memicu mereka untuk meninggalkan tanah kelahiran. Pada abad ke-18, perperangan yang terjadi di kawasan Sulawesi menciptakan kondisi yang tidak aman sehingga mereka memutuskan untuk melakukan migrasi. Selain itu, masalah ekonomi juga menjadi salah satu alasan menyebarnya orang Bugis ke berbagai daerah disebabkan keterbatasan lahan pertanian di daerah Bone dan Wajo. ${ }^{5}$

Sementara itu di kawasan Semenanjung Melayu dan kawasan Kepulauan Riau masa itu tengah berkembang Kerajaan Johor dengan wilayah kekuasaan Johor, Riau, Lingga

3 Suwardi Mohammad Samin, "Kerajaan Dan Kesultanan Dunia Melayu: Kasus Sumatra Dan Semenanjung Malaysia", dalam Jurnal Criksetra, Volume 4, Nomor 7, Februari 2015), h. 65-68

${ }^{4}$ Daud Kadir, dkk, Ibid.,

5 Mochtar Naim. Merantau: Pola Migrasi Suku Minangkabau, (Yogyakarta: Gadjah Mada University Press, 1979), h.42 
dan Pahang. Pasca jatuhnya Malaka ke tangan Portugis, Kerajaan Johor merupakan salah satu kerajaan yang berkembang di kawasan tersebut. Di penghujung abad ke-17, kerajaan mulai dilanda konflik perebutan kekuasaan dengan melibatkan Raja Kecik yang mengaku sebagai keturunan Sultan Mahmud Syah II dengan Tun Abdul Jalil sebagai pengganti sultan. ${ }^{6}$

Konflik perebutan kekuasaan ini kemudian tidak terlepas dari keterlibatan para bangsawan Bugis yang masa itu tengah berada di kawasan tersebut. Pasca direbutnya tahta kerajaan oleh Raja Kecik, aksi tuntut balas pun kemudian dilancarkan oleh keturunan Tun Abdul Jalil dengan bantuan Opu Daeng Lima Bersaudara. ${ }^{7}$ Keberhasilan Keturunan Tun Abdul Jalil, Tengku Sulaiman bersama orang-orang Bugis tersebut kemudian mengantarkannya menjadi sultan di Kerajaan Johor, Riau, Lingga dan Pahang dan para orang-orang bugis tersebut mendapat posisi strategis di dalam kerajaan.

Salah satu hal menarik dari persoalan ini adalah masuknya orangorang Bugis ke dalam struktur pemerintahan Kerajaan Melayu. Sebagaimana dijelaskan di awal, kedatangan Orang Bugis ke Tanah Melayu sejak masa-masa sebelumnya bukanlah dalam rangka ekspansi maupun mencari kekuasaan, melainkan mencari penghidupan atau sekedar ingin lepas dari kondisi politik di daerah mereka yang mulai tidak kondusif. Bersinggungan dengan kepentingan politik keluarga kerajaan Melayu kemudian membawa Opu Daeng Bersaudara ke dalam struktur pemerintahan kerajaan. ${ }^{8}$

Beberapa litersi yang berkaitan dengan keterlibatan orang Bugis dalam

\footnotetext{
${ }^{6}$ Faisal Sofyan, Op.cit., 55-57

${ }^{7}$ Opu Daeng Lima Bersaudara adalah sebutan lain bagi keturunan Daeng Rilakka.

${ }^{8}$ Ibid.. h.62
}

struktur pemerintahan kerajaan Melayu belumlah terlalu banyak. Beberapa penelitian yang pernah membahas hal serupa di antaranya adalah artikel Sunandar berjudul Melacak Hubungan Kesultanan Sambas dan Bugis yang dimuat di Jurnal Khatulistiwa pada tahun 2014, artikel tersebut berupaya melacak hubungan yang pernah terjadi antara Orang Bugis dengan Kesultanan Sambas.' Penelitian lainnya adalah makalah dalam International Seminar on Generating Knowledge Through Research, UUMUMSIDA yang digelar di Universiti Utara Malaysia, Malaysia pada tahun 2016, berjudul Bugis di Kedah 1600-1800: Suatu Tinjanan Awal yang ditulis oleh Jasni bin Ahmad. Dalam artikel tersebut Jasni menulis upaya orang Bugis untuk mengambil alih pemerintahan di Kerajaan Kedah. ${ }^{10}$ Sementara dalam literatur lain masalah ini hanya menjadi bagian tertentu dari sebuah kajian.

Maka, penelitian ini merupakan penelitian sejarah dengan mengambil batasan temporal pada abad ke-17 dan 18 . Batasan ini diambil lantaran perebutan kekuasaan kerajaan johor yang melibatkan orang Bugis terjadi pada akhir abad ke-17 dan mulai menjalankan tugas sebagai Yang Dipertuan Muda pada awal abad ke-18. Sementara itu batasan tematis dari penelitian ini terkait dengan keterlibatan orang Bugis dalam strutur pemerintahan kerajaan Melayu.

Terdapat beberapa langkah yang dilakukan dalam penelitian sejarah, seperti heuristik, kritik sumber, interprestasi dan penulisan. ${ }^{11}$ Heuristik yang dimaksud dalam penelitian ini adalah pengumpulan

9 Sunandar, "Melacak Hubungan Kesultanan Sambas Dan Bugis", dalam , Volume 4 Nomor 2 September 2014

10 Jasni bin Ahmad, "Bugis di Kedah 1600-1800: Suatu Tinjauan Awal", dalam Proceeding of ICECRS, 1 (2016), Universiti Utara Malaysia, Malaysia.

${ }^{11}$ Irhash. A. Shamad. Ilmu Sejarah. (Jakarta: Hayfa Press, 2003), h.92 
sumber-sumber berkaitan dengan peristiwa yang terjadi seputaran abad ke17 dan 18 di kerajaan Johor-Riau-LinggaPahang, serta sumber tentang keberadaan dan eksistensi orang Bugis di kawasan tersebut, baik itu data primer maupun sekunder. Sumber-sumber yang telah terkumpul, nantinya dilakukan kritik, baik itu kritik intern maupun ekstern. Dari sumber-sumber yang ditemukan, banyak terdapat kesimpang siuran data, mulai dari tahun hingga nama tempat tentang beberapa peristiwa.

Langkah selanjutnya setelah kritik sumber adalah interprestasi. Interprestasi merupakan upaya menformulasikan data agar menjadi susunan peristiwa berdasarkan data yang dinilai paling kuat dan masuk akal. Dari sinilah kemudian mulai disusun narasi sejarah terkait peristiwa yang terjadi. Sementara langkah terakhir dari penelitian ini adalah menuangkannya dalam bentuk karya ilmiah.

\section{ORANG BUGIS DALAM POLITIK DI SEMENANJUNG MELAYU}

Semenanjung Melayu merupakan kawasan yang bersentuhan langsung dengan banyak etnis yang datang dari berbagai daerah di Nusantara maupun di dunia. Selain orang Bugis maupun Minang, kawasan ini tercatat pernah didiami oleh masyarakat yang pernah bekerja pada Malaka. Tidak hanya itu, dulunya para perantau dari Bawean juga banyak menetap di daerah Malaysia maupun Singapura sekarang. Selain itu, karena merupakan kawasan perdagangan, maka keberadaan etnis Arab, Eropa, India maupu Cina juga cukup eksis di sini. $^{12}$

Dari beberapa kedatangan orang Bugis ke kawasan Semenanjung Melayu, salah satunya adalah kedatangan $\mathrm{Opu}$ Daeng Rilaka. Daeng Rilaka merupakan

12 Ahmad Dahlan, Sejarah Melayu, (Jakarta: Kepustakaan Populer Gramedia, 2014), h.208 bangsawan dari Kerajaan Luwu di Bagian Selatan Sulawesi yang datang bersama lima orang anaknya, yaitu yaitu Daeng Parani, Daeng Chelak, Daeng Marewa, Daeng Kamasi dan Daeng Maanambun. Sebelum sampai di Semenanjung Melayu, rombongan dikabarkan sempat singgah di Batavia. ${ }^{13}$

Setelah dari Batavia, rombongan Daeng Rilakka melanjutkan pelayaran ke arah utara hingga sampai di daerah Siantan yang berada di kawasan Pulau Tujuh. Di Siantan rombongan bertemu dengan seorang keturunan Bugis bernama Nakhoda Alang yang telah berganti nama menjadi Qori Abdul Malik. Dalam pertemuan tersebut, anak Daeng Rilakka, Daeng Parani mempersunting anak Qori Abdul Malik yang bernama Encik Fatimah. Selanjutnya, dalam perjalanan menuju Malaka, rombongan Daeng Rilakka bertemu dengan rombongan dari Kamboja dan ikut melakukan perjalanan ke negeri tersebut. ${ }^{14}$

Sekembalinya dari Kamboja, Rombongan Daeng Rilakka kembali merapat di Siantan. Sesampainya di Siantan, Encik Fatimah yang merupakan isteri dari Daeng Parani melahirkan anak pertama mereka, dan kemudian diberi nama Daeng Kemboja. ${ }^{15}$ Selain kelahiran Daeng Kemboja, tidak lama berselang Daeng Rilakka meninggal dunia dan dimakamkan di suatu tempat bernama Liuk. Setelah wafatnya Daeng Rilakka, pada 1681 Opu Daeng Lima Bersaudara

${ }^{13}$ Faisal Sofyan, Op.cit., h.59

14 Daud Kadir, dkk, Op.cit., h.91. Pertemuan antara rombongan Daeng Rilkka dengan rombongan dari Kamboja terjadi pelabuhan ketika mereka akan menuju Malaka. Dari pertemuan tersebut akhirnya Daeng Rilakka menerima ajakan untuk terlebih dahulu mengunjungi Kamboja. Lihat Faisal Sofyan, Op.cit., h.60

15 Pemberian nama Daeng Kemboja berkaitan dengan sebelum melahirkan, kedua pasangan yang tergabung dalam rombongan Daeng Rilakka berkunjung ke Negeri Kamboja. Faisal Sofyan, Op.cit., h.60 
melanjutkan pelayaran dan turut mendirikan pemukiman Bugis di Muara Sungai Kelang dan Sungai Johor. ${ }^{16}$

Sepanjang penelusuran terhadap keterlibatan Bugis dalam ranah politik kekuasaan, setidaknya terdapat dua kasus di kawasan Semenanjung Melayu terkait keterlibatan orang Bugis dalam urusan kekuasaan. Selain Kerajaan Johor, kasus lain juga terjadi di Kerajaan Kedah. Perebutan kekuasaan di kerajaan ini melibatkan Tunku Ngah Putera dengan sultan yang masa itu berkuasa. Tunku Ngah Putera merupakan putera dari Raja Juang Tawa dengan seorang puteri Sultan Kedah. Pergantian pemimpin pascawafatnya sultan tidak berpihak kepada Tunku Ngah Putera, sehingga ia memilih untuk undur diri kembali ke Bugis dan kembali lagi pada tahun 1687 untuk menyerang Kedah. Namun serangan dari Tunku Ngah Putera dapat diredam sehingga ia lari ke Bruas dan kemudian ke Selangor. ${ }^{17}$

Selain oleh Tunku Ngah Putera yang memiliki hubungan darah dengan kerajaan Kedah, pemberontakan lain terkait kekuasaan juga terjadi pada tahun 1770. Pada tahun tersebut terjadi penentangan dari puak (suku) di negeri Kedah yang menentang sultan lantaran usia sultan yang kian uzur dan urusan pemerintahan dijalankan oleh anaknya Tunku Abdullah gelar Yang Dipertuan Muda. Dalam penentangan tersebut, puak meminta pertolongan kepada orang Bugis. Pada 1771 pasukan Bugis sudah sampai di Kuala Sungai Kedah dan melakukan penyerangan, akan tetapi serangan tersebut dapat dilawan karena pihak kerajaan meminta bantuan kepada Inggris untuk menghalau pasukan Bugis yang datang menyerang. ${ }^{18}$

Ketika Bugis gagal meraih kemenangan dalam perebutan kekuasaan

\footnotetext{
16 Daud Kadir, Loc. Cit..

${ }^{17}$ Jasni bin Ahmad, Op.cit., h.83

${ }^{18}$ Ibid., h.83-84
}

di Kerajaan Kedah, beda cerita dengan peristiwa yang terjadi di Kerajaan Johor. Hal tersebut berawal dari Sultan Mahmud Syah II yang meninggal pada 1699 di Kota Tinggi Johor. ${ }^{19}$ Karena ketiadaan pengganti, maka pada awal September 1699 bendahara kerajaan yang waktu itu dipegang oleh Tun Abdul Jalil naik untuk mengisi posisi sultan dengan gelar Sultan Abdul Jalil Riayat Syah. ${ }^{20}$

Setelah tampuk pemerintahan dipegang oleh Sultan Abdul Jalil Riayat Syah, maka selanjutnya muncullah Raja Kecik yang mengaku sebagai keturunan dari Sultan Mahmud Syah II. ${ }^{21}$ Dalam perjalanan untuk merebut kembali kekuasaan dari Sultan Riayat Syah, Raja Kecik bertemu dengan Opu Daeng Bersaudara dan meminta mereka untuk bergabung, dengan kesepakatan apabila upaya mereka untuk merebut kekuasaan berhasil, maka Daeng Parani akan diangkat menjadi Yang Dipertuan Muda. Setelah pertemuan yang berlangsung di Muara Sungai Johor itu, maka Opu Daeng Bersaudara berangkat menuju Langat yang merupakan tempat bermukim orang Bugis di wilayah Johor. ${ }^{22}$ Selain dari orang Bugis, Raja Kecik juga mendapat bantuan dari daerah Kuala Johor dan Singapura yang mana dulunya wilayah tersebut merupakan basis pendukung Sultan Mahmud Syah. Tanpa menghiraukan kesepakatan dengan Opu Daeng Bersaudara, Raja Kecik melanjutkan perjalanan melakukan penaklukan. Dari peristiwa tersebut,

${ }^{19}$ Ahmad Dahlan, Op. cit., h.190-191

${ }^{20}$ Ibid., h.192

21 Raja Kecik diceritakan sebagai keturunan dari Sultan Mahmud Mangkat di Julang (Sultan mahmud Syah) dimana setelah sultan meninggal, ia yang saat itu masih kecil dibawa pergi dari Johor hingga kemudian ke Minangkabau, disana ia dirawat oleh penguasa Pagaruyuang. Setelah dewasa ia dibekali oleh ibu suri Kerajaan Pagaruyuang bernama Putri Jamilan untuk kembali menuntut tahtanya yang ada di Johor. Ibid., 194

22 Daud Kadir., Op.cit., h.92 
tepatnya pada 21 Maret 1717, Raja Kecik berhasil menaklukkan Johor dan diangkat menjadi sultan dengan gelar Sultan Abdul Jalil Rahmat Syah, sementara Sultan Abdul Jalil yang sebelumnya memerintah dijadikan bendahara kerajaan. ${ }^{23}$

Keterlibatan orang Bugis, yang dalam hal ini adalah anak-anak dari Daeng Rilaka berlanjut ketika adanya upaya merebut kekuasaan dari Abdul Jalil Rahmat Syah oleh anak Sultan Abdul Jalil yang saat itu sudah kembali menjabat sebagai bendahara kerajaan. Dalam beberapa sumber disebutkan Tengku Sulaiman Sultan Abdul Jalil ingin kembali merebut tahta kerajaan lantaran tidak terima karena merasa dipermainkan oleh Sultan Abdul Jalil Rahmat Syah. ${ }^{24}$ Untuk itu, Tengku Sulaiman selanjutnya meminta bantuan kepada anak-anak Daeng Rilakka agar membantunya untuk menggulingkan sultan. Hal tersebut disambut baik oleh Opu Daeng Bersaudara, sebab mereka merasa punya kepentingan untuk membalas dendam kepada Raja Kecik. Rasa tidak senang kepada Raja Kecik sudah muncul semenjak ia meninggalkan mereka ketika sudah membangun kesepakatan untuk menyerang Johor dulu.

Serangan terhadap Sultan Abdul Jalil Rahmat Syah dipimpin oleh Daeng Marewa. Serangan dari orang-orang Bugis tersebut tidak dapat ditahan sehingga pusat kerajaan dipindahkan ke daerah Riau pada thun 1719. Malangnya, dalam penyerangan tersebut, Sultan Abdul Jalil atau Datuk Bendahara ikut terbunuh oleh

${ }^{23}$ Ahmad Dahlan, Op.cit., h.196. Lihat juga Daud Kadir., Ibid.,

24 Setelah menjadi sultan, Pada awalnya Raja Kecik berniat untuk menikahi Tengku Tengah yang merupakan anak dari Datuk Bendahara atau Sultan Abdul Jalil, akan tetapi kenyataannya Raja Kecik malah menikahi Tengku Kamariah yg merupakan saudara dari Tengku Tengah. Hal ini tidak disenangi oleh keluarga Datuk Bendahara karena merasa dipermainkan. Lihat Ahmad Dahlan, Ibid., h.196 anak buah sultan. Selanjutnya, pada tahun 1722, Daeng Parani bersama saudarasaudaranya melanjutkan penyerangan ke daerah Riau dan terjadilah pertempuran di beberapa titik, seperti Pulau Penyengat, Pulau Bayan dan Tanjung Pinang. Akibat serangan tersebut akhirnya Sultan Abdul Jalil Rahmat Syah terus mundur sampai ke Lingga hingga akhirnya memutuskan untuk lari ke Siak. ${ }^{25}$

Pada 4 Oktober 1722, Tengku Sulaiman kemudian dilantik sebagai Sultan Kemaharajaan Melayu dan seluruh daerah taklukannya dengan gelar Sultan Sulaiman Badrul Alamsyah I. Sejak saat itu, kerajaan yang berkuasa atas daerah Johor, Pahang, Riau dan Lingga itu dikenal dengan Kerajaan Riau, sementara Daeng Marewa dianugerahi jabatan sebagai Yang Dipertuan Muda. ${ }^{26}$ Tempat yang dijadikan sebagai pusat pemerintahan itu dikenal dengan Istana Kota Piring yang berada di Pulau Bintan. Istana tersebut mulai difungsikan sejak penabalan atau pelantikan Sultan Sulaiman hingga 10 November $1784 .^{27}$

Selain diberikan jabatan sebagai Yang Dipertuan Muda, Opu Daeang Bersaudara juga diikat oleh Sultan Sulaiman melalui pernikahan dengan kerabat kerajaan. Daeng Parani dinikahkan dengan adik Sultan Sulaiman, Tengku Tengah. Sementara Daeng Marewa dinikahkan dengan Tun Cik Ayu yang merupakan anak dari Tumenggung Johor. Daeng Chelak dinikahkan dengan Tengku Mandak, adik Sultan Sulaiman yang lain. ${ }^{28}$ Anak yang menjadi keturunan Melayu-Bugis ini kemudian bergelar 'Raja' sebagai simbol kebangsawanan. ${ }^{29}$

${ }^{25}$ Ibid., h.198-199

${ }^{26}$ Ibid., h.201-203

27 Totok Roesmanto, Rekonstruksi Arsitektur Istana Kota Piring, (Jurnal Dimensi Teknik Arsitektur, Vol. 32, No. 1, Juli 2004), h.33

${ }^{28}$ Faisal Sofyan, Op.cit., h.62

29 Ahmad Dahlan, Op.cit., h.204 


\section{YANG DIPERTUAN MUDA DAN PERUBAHAN STRUKTUR KERAJAAN}

Diangkatnya Daeng Marewa sebagai Yang Dipertuan Muda Riau I menjadi titik balik dari sistem pemerintahan Kerajaan Johor-RiauLingga-Pahang. $\mathrm{Hal}$ ini merupakan sesuatu yang tidak biasa dalam sebuah pemerintahan Kerajaan Melayu. Sebagaimana yang dijelaskan sebelumnya, di Kerajaan Kedah, Tun Ngah Putera yang mencoba untuk mengambil alih kekuasaan mengalami kegagalan dan harus menderita kekalahan setelah mengumpulkan pasukan dari Bugis. Akan tetapi, di Kesultanan Johor begitu berbeda. Jabatan sebagai Yang Dipertuan Muda diperoleh keturunan Daeng Rilakka setelah bekerja sama dengan salah satu pihak yang memiliki kepentingan terhadap kekuasaan.

Jabatan sebagai Yang Dipertuan Muda bukanlah jabatan rendah untuk ukuran kerajan Melayu masa itu. Yang Dipertuan Muda dapat dikatakan sebagai jabatan tertingi kedua setelah jabatan sultan yang disebut dengan Yang Dipertuan Besar. Pada masa sebelumnya, jabatan Yang Dipertuan Muda sama dengan jabatan Bendahara Kerajaan. Artinya, selain di tangan Sultan, urusan negeri ada di tangan Yang Dipertuan Muda.

Lebih lanjut, Ridwan Melay dalam tesis berjudul Riau Lingga Dilema Kekuasaan dan Implikasi Perdagangan 17841824 menuliskan sebelumnya di Kerajaan Johor dikenal struktur pemerintahan sultan. Dalam pemerintahan tersebut sultan dibantu oleh Bendahara, Laksmana, Temenggung serta Orang Kaya. Pemangku jabatan ini memiliki jaringan ke masyarakat serta pihak asing dan hubungan mereka juga saling berkaitan antara satu dengan yang lain. ${ }^{30}$ Terkait pentingnya posisi bendahara kerajaan, sebelum pemerintahan sampai ke tangan Sultan Sulaiman Badul Alamsyah I, segala urusan diurus oleh sultan, menteri dan bendahara. Orang-orang yang akan mengisi jabatan tersebut dipilih langsung oleh sultan dan akan mempertanggungjawabkan seluruh pekerjaan kepada istana. Lebih dari pada itu, sultan juga memiliki ketergantungan terhadap bendahara maupun menteri. ${ }^{31}$ Dengan keberadan Yang Dipertuan Muda, maka posisi atau jawatan Bendahara Kerajaan pun ditiadakan. ${ }^{32}$

Selain itu, Ahmad Dahlan dalam buku Sejarah Melayu menyebutkan posisi sebagai Yang Dipertuan Muda dapat disebut sebagai wakil sultan atau sekelas dengan perdana menteri, ${ }^{33}$ sehingga dalam posisi tersebut sangat memungkinkan pemangkunya untuk mengambil kebijakan strategis di lingkungan kerajaan. Sementara pada masa pemerintahan sebelumnya hal tersebut dipercayakan kepada pemegang jabatan menteri serta Majelis Orang Kaya Melayu. Sehingga dengan adanya Yang Dipertuan Muda maka membuka peluang bagi pihak yang tidak lagi memiliki jabatan berubah menjadi oposisi. ${ }^{34}$

Jabatan Yang Dipertuan Muda juga memiliki kekuasaan yang cukup besar. Padanya mencakup jabatan Panglima Perang dan hubungan luar negeri. Sementara jabatan Yang Dipertuan Besar atau sultan hanya mengurus perihal adat istiadat, agama,

30 Ridwan Melay, Riau Lingga Dilema Kekuasaan dan Implikasi Perdagangan 1784-1824, (Tesis Ilmu Sejarah UI, 1999), h.55

${ }^{31}$ Ibid., h.33-34

${ }^{32}$ Faisal Sofyan, Op.cit., h.64

33 Ahmad Dahlan, Op.cit., h.203

${ }^{34}$ Ridwan Melay, Op.cit., h.40 
hukum, serta keamanan di dalam negeri. ${ }^{35}$ Dengan kata lain, Yang Dipertuan Besar lebih mengurus pada urusan dalam negeri dan Yang Dipertuan Muda mengemban tugas untuk mengurus pertahan serta urusan eksternal kerajaan.

Lambat laun, kondisi ini mulai memperlihatkan ketimpangan dengan mendominasinya peran dari Yang Dipertuan Muda. Persoalan ini pun menjadi persoalan yang mandasar dalam internal kerajaan. Dengan masuknya orang Bugis ke dalam struktur pemerintahan kemudian mulai mengenyampingkan peran sultan. Tidak dapat dipungkiri bahwasanya keikutsertaan orang Bugis dalam perebutan kekuasaan akhirnya merubah struktur pemerintahan tradisional kerajaan Johor hingga akhirnya bubar sebagai Kerajaan Riau Lingga. ${ }^{36}$

Ketimpangan tersebut kemudian berubah menjadi konflik internal kerajaan. Sejak dijabatnya Yang Dipertuan Muda I oleh Daeng Marewa telah terjadi beberapa konflik, akan tetapi hal tersebut dapat kembali menemui titik temu sehingga masing-masing pihak kembali dapat menjalankan tugasnya masing-masing. Selain konflik politik antara Yang Dipertuan Besar Sultan Mahmud Muzaffar Syah dengan Yang Dipertuan Muda Raja Abdul Rahman, sebelumnya juga terjadi hal serupa, sehingga terjadi kekosongan jabatan Yang Dipertuan Muda selama lebih kurang tiga tahun. $^{37}$

35 Rida K Liamsi, "Berhutang Pada Persebatian Melayu Bugis", dalam Firdaus L.N dkk, Tamadun Melayu Lingga (Dinas Kebudayaan Kabupaten Lingga, 2018), h.39

${ }^{36}$ Keterlibatan Orang Bugis sebagai Yang Dipertuan Muda terus bertahan hingga kerajaan Johor beralih menjadi Kerajaan Riau Lingga dan akhirnya bubar pada awal abad ke-20. Ahmad Dahlan, Op.cit., h.203. Lihat juga Ridwan Melay, Op.cit., h.55

37 Perselisihan antara Sultan Mahmud Muzaffar Syah dengan Yang Dipertuan Muda Raja
Setelah wafatnya Daeng Chelak sebagai Yang Dipertuan Muda II pada tahun 1745, posisi tersebut sempat mengalami kekosongan. Hal tersebut terjadi lantaran adanya rasa ketidaksengangan pihak Melayu terhadap kekuasaan orang Bugis. Karena jabatan Yang Dipertuan Muda merupakan posisi yang diberikan oleh Sultan Sulaiman, maka pihak-pihak yang tidak senang menghasut sultan untuk mengurangi dominasi orang Bugis. Akan tetapi pada tahun 1948, permasalahan ini kembali mereda setelah diadakan perdamaian antara Daeng Kemboja dengan Sultan Sulaiman. Pada tahun itu Daeng Kemboja kembali mengisi kekosongan jabatan Yang Dipertuan Muda sebagai Yang Dipertuan Muda Riau III. ${ }^{38}$

Memasuki masa Yang Dipertuan Muda Riau IV yang dijabat oleh Raja Haji, ikatan persaudaraan yang dijalin antara Melayu dengan Bugis semakin kuat. Raja Haji dikenal sebagai sosok Melayu Bugis yang memahami Melayu secara kultur. ${ }^{39}$ Pada masanya, Kemaharajaan Melayu dinilai mulai mencapai keberhasilan dengan berbagai pencapaian serta disegani di sepanjang Selat Malaka dan Pesisir Timur Sumatera. Keberadaan pelabuhan atau bandar dengan cukai keluar masuk barang serta penimbunan barang di pelabuhan ikut memberikan dampak terhadap peningkatan perekonomian. ${ }^{40}$

Dalam bidang pendidikan, pada masanya juga dilakukan pemberantasan terhadap buta huruf hijaiyah dan mulai mempelajari Aksara Arab Melayu. Dari sektor keamanan dan pertahanan, kekuatan dan kapasitas armada laut juga mulai ditingkatkan, sembari dibarengi

\footnotetext{
Abdul Rahman dapat diselesaikan sertelah kembali mengulang pengucapan sumpah setia antara kedua belah pihak. Rida K Liamsi., Ibid.,

${ }^{38}$ Daud Kadir., Op.cit., h.96

${ }^{39}$ Rida K Liamsi, Op.cit., h.39

${ }^{40}$ Daud Kadir., op.cit., h.97
} 
dengan pembangunan benteng-benteng pertahanan. ${ }^{41}$ Pada beberapa pertempuran dengan pihak kompeni Raja Haji kerab membawa kemenangan bagi pihak Melayu. Sekalipun demikian, tidak jarang pula pertempuran tersebut berakhir dengan kekalahan lantaran pihak lawan dilengkapi dengan persenjataan yang lengkap. Selain itu, Raja Haji juga tidak lagi menggunakan 'Daeng' di awal namanya, akan tetapi menggunakan 'Raja'. ${ }^{42}$

\section{Para Yang dipertuan Muda Riau ${ }^{43}$}

1) Daeng Marewah / Yang Dipertuan Muda Riau I (1722-1728) Merupakan anak Daeng Rilakka.

2) Daeng Chelak / Yang Dipertuan Muda Riau II (1728-1745) - Merupakan anak Daeng Rilakka.

3) Daeng Kamboja / Yang DipertuanMuda Riau III (1748-1777) Merupakan anak dari Daeng Parani dengan Encik fatimah.

4) Raja Haji / Yang Dipertuan Muda Riau IV (1777-1784) - Merupakan anak dari Daeng Chelak yang menikah dengan adinda Sultan Sulaiman Johor.

5) Raja Ali / Yang Dipertuan Muda Riau V (1784-1806) - Merupakan anak dari Daeng Kemboja.

6) Raja Jaafar / Yang Dipertuan Muda Riau VI (1806-1831) - Merupakan anak dari Raja Haji.

7) Raja Abdul Rahman / Yang dipertuan Raja Muda Riau VII (18331843) - Merupakan anak dari Raja Jaafar. Diangkat pada 2 Desember 1833 lantaran tidak ditemukan pengganti dan Sultan Abdurrahman juga terlebih dulu sakit dan mangkat di Lingga. Ia diangkat oleh Sultan Muhammad Syah di Lingga. ${ }^{44}$

\footnotetext{
41 Ibid., h.98

${ }^{42}$ Ridwan Melay, Op.cit., h.8

${ }^{43}$ Faisal Sofyan, op.cit., h.141-160. Lihat juga Daud Kadir., op.cit., h.95-99

${ }^{44}$ Daud Kadir., op.cit., h.184-185
}

8) Raja Ali/ Yang Dipertuan Muda Riau VIII (1845-1857) - Merupakan anak Raja Jaafar.

9) Raja Abdullah/ Yang Dipertuan Muda Riau IX (1857-1858) - Merupakan anak Raja Jaafar.

10) Raja M. Yusuf/ Yang Dipertuan Muda Riau X (1858-1899) - Merupakan anak Raja Ali dan cucu dari Raja Jaafar. Raja M Yusuf kemudian menikahi Tengku Embung Fatimah. Dari pernikahan tersebut lahir Raja Abdurrahaman yang kemudian menjabat sebagai sultan Kerajaan Riau Lingga dengan gelar sultan Abdurrahman Muazamsyah II dan merupakan sultan terakhir tersebut sebelum dibubarkan oleh Belanda pada tahun 1913. ${ }^{45}$

\section{PENUTUP}

Kehadiran orang Bugis dalam Kerajaan Johor-Riau-Lingga-Pahang membawa perubahan yang berarti dalam struktur pemerintahan kerajaan tersebut. Tak dapat dipungkiri bahwa sistem pemerintahan tradisional kerajaan Melayu mulai berubah seiring masuknya Bugis dalam struktur pemerintahan sebagai Yang Dipertuan Muda. Jabatan yang diberikan oleh Sultan Sulaiman Badrul Alamsyah I itu khusus diperuntukkan bagi keturunan Daeng Rilakka yang telah membantunya merebut tahta dari Sultan Abdul Jalil Rahmat Syah.

Posisi sebagai Yang Dipertuan Muda dapat disamakan dengan posisi seorang perdana menteri. Ketika penabalan atau pengukuhan Sultan Sulaiman sebagai sultan serta penunjukan Daeng Marewa sebagai Yang Dipertuan Muda, secara otomatis beberapa jabatan lama seperti bendahara kerajaan dihapuskan. Jabatan yang dipegang oleh keturunan Bugis itu berlaku turun temurun dari generasi ke generasi.

Kiprah Yang Dipertuan Muda selanjutnya dinilai sangat mendominasi,

${ }^{45}$ Ibid., h.189 
sehingga secara tidak langsung mengenyampingkan sultan sebagai Yang Dipertuan Besar. Ketidaksenangan dari sebagian Melayu menjadi halangan tersendiri bagi keturunan Bugis, akan tetapi persoalan-persoaln tersebut tetap dapat teratasi dengan diplomasi serta pengulangan kembali sumpah setia Melayu Bugis. Dalam perkembangannya, dedikasi para Yang Dipertuan Muda untuk membangun, mengembangkan serta mempertahankan Kerajaan Riau Lingga mulai menghilangkan batas antara Melayu dan Bugis.

\section{DAFTAR PUSATAKA}

Ahmad, Jasni bin, "Bugis di Kedah 16001800: Suatu Tinjauan Awal", dalam Proceeding of ICECRS, 1 2016, Universiti Utara Malaysia, Malaysia, 2016.

Dahlan, Ahmad. Sejarah Melayu. Jakarta: Kepustakaan Populer Gramedia, 2014.

Kadir, Daud, dkk. Sejarah Kesultanan Lingga-Riau. Pemerintah Kabupaten Lingga Provinsi Kepulauan Riau, 2008.

Liamsi, Rida K, "Berhutang Pada Persebatian Melayu Bugis", dalam Firdaus L.N dkk, Tamadun Melayu Lingga. Dinas Kebudayaan Kabupaten Lingga, 2018

Mansyur, "Migrasi Dan Jaringan Ekonomi Suku Bugis di Wilayah Tanah Bumbu, Keresidenan Borneo Bagian Selatan dan Timur 1930-1942", dalam Jurnal Sejarah Citra Lekha, Vol. 1, No. 1, 2016.

Melay, Ridwan. Riau Lingga Dilema Kekuasaan dan Implikasi Perdagangan 1784-1824. Jakarta: Tesis Ilmu Sejarah UI, 1999.

Naim, Mochtar. Merantau: Pola Migrasi Suku Minangkabau. Yogyakarta: Gadjah Mada University Press, 1979.
Omar, Rahilah, dkk, "Sejarah kedatangan masyarakat Bugis ke Tanah Melayu: Kajian Kes di Johor", dalam Jebat 36, 2009.

Samin, Suwardi Mohammad, "Kerajaan dan Kesultanan Dunia Melayu: Kasus Sumatra Dan Semenanjung Malaysia", dalam Jurnal Criksetra, Volume 4, Nomor 7, Februari 2015.

Shamad, Irhash. A. Ilmu Sejarah. Jakarta: Hayfa Press, 2003.

Sunandar, "Melacak Hubungan Kesultanan Sambas dan Bugis (Studi Awal terhadap Naskah Tuhfat al-Nafis)", dalam Jurnal Khatulistiwa - Journal of Islamic Studies, Volume 4 Nomor 2 September 2014.

Sofyan, Faisal. Sejarah Persemendaan Melayu dan Bugis. Tanjung Pinang: Milaz Grafika, 2013.

Syahri, Aswandi, Raja Murad. Cogan Regalian Kerajaan Johor-Riau-LinggaPahang. Dinas Pariwisata, Seni dan Budaya Provinsi Kepulauan Riau, 2006.

Totok Roesmanto, "Rekonstruksi Arsitektur Istana Kota Piring", dalam Jurnal Dimensi Teknik Arsitektur, Vol. 32, No. 1, Juli 2004.

Umar. Perantau Bugis dalam Narasi Sejarah: Sebuah Kritik Historiografi. Yogyakarta: Tesis Ilmu Religi dan BudayaUniversitas Shanata Dharma, 2018. 